\title{
THE PROBLEM OF REFORMING PROCEDURE
}

\author{
By Henry Upson Sims, of the Alabama Bar.
}

So much is being heard now of the formalities and delays incident to the trial of causes in American courts, that a reform wave seems to be imminent, strong enough to wipe away much of the framework upon which our courts now stand. The demands for reform generally heard are those directed against the procedure in the Federal courts; for the reason that Congress and the bar of the entire country can work in unison upon reforming that system. A special standing committee of the American Bar Association has been working since I9O7 to the end, ${ }^{1}$ and the movement has been endorsed by the Chief Justice of the United States in appointing a committee to reform the rules of equity practice of the Supreme Court, ${ }^{2}$ as well as local committees to consider the revision of the local equity rules in the several circuits. But the assault is by no means confined to Federal procedure. In many of the States commissions are working upon the reform of State judicial procedure ${ }^{3}$ and where the agitation has not reached the state of legislative recognition, it is spreading in the form of papers and resolutions to be found in the proceedings of the several State bar associations.

This general demand for reform will doubtless result in the tearing down and rebuilding of much that is worn out or weak in the judicial structure throughout the country; and in that light its coming should be hailed with satisfaction. But it must not be unhesitatingly accepted as the arrival of the age of legal enlightenment, all wise in reconstructing the framework of the law; for these waves of reform have come before, and the obsolete structures they have washed away have been sometimes replaced by

1 See especially their report to the Association in 1910, and in 1911. Volumes 35 and 36 of the Reports of the American Bar Association.

$2 \mathrm{Mr}$. Justice Lurton of the Supreme Court was in England the past summer conferring with the judges of His Majesty's High Court of Justice upon the workings of their procedure.

${ }^{8}$ For example, a bill prepared to reform procedure in Illinois seems to have been under discussion for some time. See 35 Reports Americax Bar Association, 644. And the State of New York recently created a commission to investigate the law's delay. 
others whose imperfections were not all traceable by their newness.

The first wave of reform in procedure passed over America after the adoption of the New York Code of Civil Procedure in i848. California, Missouri, Texas, Indiana, Ohio, Minnesota, Wisconsin, Iowa, Washington, and Nebraska, adopted the plan of New York within about ten years thereafter. Then came Georgia, Kansas, Idaho, Nevada, Arizona and Oregon, all before the close of the Civil War. And a little later, probably due to the reconstruction regime in the South, the New York plan was .installed in four more States in the South, North Carolina, South Carolina, Arkansas and Florida, although Florida abolished the Code in 1873 .

England reconstructed its courts and revolutionized its procedure in $1873^{4}$ and this may be considered the beginning of the second wave, reaching in the United States, Colorado in 1877 , Connecticut in 1879 , Wyoming in 1886 , Oklahoma in 1890 , Kentucky in I89r, and New Mexico in I897.5 Since then no more States have adopted revolutionary changes.

For the inspiration, if not the preparation, of the earlier codes, that of New York was doubtless the basis; althaugh after they had multiplied as they did by the '7o's, it would be difficult to identify the sources of the various revisions in the Codes as they subsequently appeared. For example, every ordinary judicial proceeding under the New York Code is termed "an action", ${ }^{8}$ and this same term was prescribed later for all suits in South Carolina, ${ }^{\top}$ and was subsequently adopted in England. ${ }^{8}$ And while it is therefore probable that in each instance the term was adopted from New York, so many differences are to be found between the New York Code and that of South Carolina and the Judicature Act in England, that the similarities in anything but essential principles

4 This was done by the Supreme Court of Judicature Act of 1873, 36 and 37 Victoria Ch., 66.

- For a ready reference to the statutes in the various States adopting codes of procedure and the years of their passage, see 16 Cyclopedia of Law and Procedure, p. 24.'

- Code Civ P., Sec. 3333.

7 Code of 1870, xiv, Sec. 423.

8. Iudicature Act of 1873, Rule I, of Rules of Practice annexed. 
-f providing uniform pleadings in every suit, are probably not enough to indicate that one was based upon the other. ${ }^{9}$

It may be doubted therefore whether much more than the general scheme of the earlier codes was adopted by those who prepared the later ones, the details in each case being framed rather upon the theoretic judgment of the draftors than upon a careful comparison of the successes and failures in codes which were in use beforehand.

It seems to be a mark of mankind to be less careful in selecting his laws than in selecting any other implement by which he applies his energies. Forgetful that the effectiveness of his efforts in the relations of life is directly dependent upon the efficiency of the rules limiting their operation, he adopts laws which will prescribe his future actions for an indefinite duration with little or no opportunity to verify the soundness of his conclusionslaws which, if inefficient will cause society more waste of time and mental effort than any untried physical invention he might employ. And yet he will not adopt physical inventions until their efficiency has been tested under prolonged study of their adaptability.

The rapidity with which the several States first following the example of New York adopted codes providing a uniform procedure, precluded any careful investigation of the practicability of the New York plan. The notion of a uniform procedure in asserting every right, and the privilege of obtaining the recognition of every right in every court, were essentially pleasing to the casual student; and the information that these desiderata were being accomplished in New York and such other States as may have already followed New York, were persuasive to the experiment. But if it is surprising that the many codes of pro-

${ }^{\circ}$ Chief Justice (now Governor) Simeon E. Baldwin of Connecticut, writing upon "Pleading in Civil Actions" in a volume of essays entitled "Two Centuries Growth of American Lawe" published by Yale University in 1901, says that Connecticut in drawing her Code of 1877, adopted a certain leading feature of the rules appended to the English Judicature Acts of 1873; which is doubtless true. But he says also that England "followed the example" of those American States who had already adopted a code; and if this means that they "adopted" the principles of the American Codes, it does not seem to be admitted in England. Although the origin of the Judicature Acts is discussed in several articles in the ninth and tenth editions ' of the Encyclopedia Brittanica, it is always with that complacency characteristic of the British mind when contemplating its own work. 
cedure drafted throughout the United States before the end of the Civil War were adopted without an adequate opportunity to test the workings of the Code in New York, with what interest we note the incaution with which New York, herself, discarded the systems of procedure used by English speaking peoples throughout their entire history in exchange for a system entirely new and clearly in conflict with hitherto accepted principles of jurisprudence!

"When the Constitution of 1846 (New York) was adopted, it provided-for the appointment of three commissioners to revise, reform and simplify the rules of practice, pleadings, forms and proceedings of the courts of record of the State. Aphaxid Loomis, Nicholas Hill, Jr., and David Graham were appointed commissioners on practice and pleadings, and in 1847 , Messrs. Graham and Loomis (Mr. Hill having resigned) reported to the legislature their determination to present a new system of practice and pleading, abolishing the distinction between modes of procedure in case of legal and equitable cognizance and the adoption of a uniform system as applicable to all cases. This report was followed at the next session of the legislature by the enactment of the Code of Procedure (April r2, I848), submitted by the Commissioners above named and David Dudley Field, who had been added to their number..$^{10}$

It was after more prolonged study that England abolished the old procedure and created her present system of courts and practice as involved in the Judicature Acts. The change was recommended by a commission appointed in 1867 , which first reported its conclusions in 1869 , and again in 1872 , and upon these the Act of 1873 was based. ${ }^{11}$ And undoubtedly the English system as embodied in this first Act, together with the rules of practice appended to it, reveals in its flexibility the thorough study bestowed upon it by its inventors. ${ }^{12}$ But except for the principal

${ }^{10}$ James L. Bishop, Code Procedure in Personal Actions, (N. Y.), Sec. 28.

11 It seems that the first act was passed in 1871. See Ency. Britt., 9th Ed., v. 2, p. 261; but no such Act appears in the volume of British Statutes for 1871, published with the Law Reports. The Judicature Act of 1873 is in the volume for that year. 36 and 37 Victoria Ch., 66.

12 The motion for the commission was made in Parliament by Sir Roundell Palmer (Lord Selborne), and much of its work seems to have been done by him. He carried the Act through Parliament; and he seems to have been the chief author of the Rules of Procedure under it. At least 
features, a combined jurisdiction of the courts, and a uniform method of procedure involving "the fusion of law and equity which was the dominant legal idea of law reformers of that period," 13 the provisions of the new system were entirely original with its framers, without even the support of the experience of New York; so that the test of study alone, however prolonged, hardly justifies the alacrity with which a system of procedure so revolutionary was applied to all the civil courts at once. While the plan of a uniform procedure must have been postponed, if the new method of procedure had been tested first, yet it is believed that the plan adopted should have been put to test in Chancery before it was imposed upon the courts which had to enforce the common law. ${ }^{14}$

Of course it is not presumed to argue that the codes adopted by the several States and the procedure provided by the Judicature Acts are failures. Nor would it be within the scope of this article to do so. It is merely desired to show by reference to some of the systems adopted, and no better examples could be chosen than those of New York and England,--that while they may be more acceptable in the main to those practicing under them, than the old systems as they were when abolished, their development has brought much disappointment and has revealed problems involved in their application which have not yet been

he regarded the Act and the rules as his chief claim to fame. See 32 Ency. Britt., 10th Ed., p. 510, title, Lord Selborne, written by Sir Edward Fry.

${ }^{13}$ Language of Lord Davey. See his discussion of the Judicature Acts in 30 Ency. Britt., 10th Ed., p. 146.

14 ibid. Compare on the other hand the conservatism with which the English viewed radical changes in the sphere of mechanics. In 1878 Parliament passed the last of several Acts fortifying the use by horse drawn vehicles of the public roads against a possible invasion by motor wagons. And this law was not repealed until 1896, by which time France, Germany, and even America were far ahead of England in the development of automobiles. See 31 Ency. Britt., 10th Ed., p. 11. And as an example of American conservatism in mechanics, let it be recalled that French, German, Italian, and English manufacturers of automobiles had discovered by 1906 or 1907 the efficiency of the "long stroke" for internal combustion engines, so that probably seventy-five per cent of the machines turned out during the last five years by European manufacturers have a relation of stroke of piston to diameter of cyclinder, of at least $1 / 2$ to 1 ; whereas not until the output for 1912 have the American makers generally accepted the long stroke motor. See the current numbers of The Automobile or The Motor. 
solved. It will then be suggested that these problems were unavoidably incident to creating a system instead of reforming one, and that some of them arose from a disregard of fundamental principles of jurisprudence.

The New York Code provided that "there is only one form of civil action. The distinction between actions at law and suits in equity and the forms of those actions and suits have been abolished."1s And the first conception was that the complaint must contain merely a plain and concise statement of the facts without unnecessary repetition. ${ }^{16}$ But as the law was amended in $185^{2}$ the plaintiff might unite in the same complaint several causes of action, whether they.be such as had theretofore been denominated legal or equitable, or both, where they all arose out of the same transaction or transactions connecting with the same subject of action. $^{17}$

This amendment would seem to have been a return to the theory of common law counts, but in the celebrated spurious stock issue case of The New York, New Haven and Hartford Railroad Co. v. Schuyler and three hundred and twenty-five others, ${ }^{18}$ the court relied upon it in order to maintain the former scope of equitable actions. The Court held that all the defendants were properiy sued at once, saying, "This provision was introduced in the Amendment of 1852 , because the successive Codes of 1848 , I849 and $185 \mathrm{I}$, with characteristic perspicacity, had in effect abrogated equity jurisdiction in many important cases, by failing to provide for a union of subjects and parties in one suit indispensible to its exercise. This amendment, therefore, was not designed to introduce any novelty in pleading or practice. Its language is, I think, well chosen for the purpose intended, because it is so obscure and so general as to justify the interpretations which shall be found most convenient and best calculated to promote the ends

- of justice. It is certainly impossible to extract from a provision so loose and yet so comprehensive any rules less liberal than those which have long prevailed in courts of equity." 10

\footnotetext{
${ }^{15}$ Sec. 3339 of present Code.

${ }^{16}$ Sec. 481.

17 Code of 1855 , Sec. 167.

1817 New York, 592.

19 Per Comstock, J. Whether those 326 defendants could have been joined in every jurisdiction following the procedure of old English Chancery, it is plain that the New York Court thought they could have been joined under the old practice.
} 
How much havoc was played before the amendment of 1852 was held to restore the jurisdiction of the court to the scope it enjoyed under the old chancery practice, can never be known.

But whether associated with the amendment of 1852 or not, the theory of common law counts did not fail to reassert itself. Disappointing limitations in the broad language of the Code appeared in connection with the proof of the cause of action. If the "plain statement of facts constituting the cause of action" approximated the aggregate which would have served as the basis for one of the former common law writs, as in an action on the case for deceit, and the aggregate of facts proved would have sustained by common law an action on the case in assumpsit, the plaintiff in New York failed; because, in the language of the Court, he had "made a statement of facts which did not constitute his cause of action." analogy to common law counts was allowed, if the cause of action proved was not among those stated, the plaintiff was not allowed to sue again, but was cast. in his suit. ${ }^{21}$

As a result of these conclusions the old requirement of an election of remedies was recognized, ${ }^{22}$ and the Code now gives the additional warning that the different causes of action set forth as sued on must be consistent with each other in conformity with certain classifications of rights capable of being joined, as upon contracts, or for personal injury, or for injury to realty, and so forth. ${ }^{23}$

It is thus evident that the old common law disaster of non-conformity of allegations and proof has not been eliminated in New York; and that a "simplified" system of statement has not. proven effective to this end.

With regard to defensive pleadings the New York Code assimilated the English Chancery practice, and endeavored to draw the common law side of the court in that direction. It provided an answer consisting in substance of two parts, first an answer or denial of the matter of the complaint, and secondly, the defend-

${ }^{20}$ Ross v. Mather, 51 N. Y., 108.

21 Walter v. Bennett, 16 N. Y., 250. And compare Salisbury v. Howe, 87 N. Y., 128.

${ }^{22}$ Bishop's Code Practice (N. Y.), Sec. 158.

${ }^{23} \mathrm{Sec} 484$ of the present Code. 
ant's defenses. ${ }^{2 t}$ And in every case the defenses must embrace both those legal and equitable. ${ }^{25}$

With defenses were included counter claims, with the purpose as worked out by the new theorists, of disposing of all matters connected with the litigation in a single suit; but the scope of counter claims was limited to the issues laid out by the complaint; and as analyzed by $\mathrm{Mr}$. Bishop, ${ }^{28}$ the allowable counter claim under the present Code must

"I. Tend in some way to diminish or defeat the plaintiff's recovery.

"2. Be a cause of action.

"I. Either (I) arising out of the contract, or (2) the transaction set forth in the complaint, or (3) connected with the subject of the action.

"2. Or in an action on contract or any other cause of action on contract existing at the commencement of the action.

"3. Against the plaintiff, or in a proper case against his assignor and in favor of defendant."

The decisions supporting and delimiting these propositions; seem to hold that the counter claim can in no sense involve a separate transaction ${ }^{2 \pi}$ it must be a definite cause of action, of which the court has jurisdiction; ;8 it must be a claim of the defendant alone against the plaintiff alone $;^{29}$ and it must exist at the commencement of the original action. ${ }^{30}$

These provisions are supposed to allow what is ordinarily known as legal and equitable set off and recoupment. And against actions for torts they are said to allow set offs of counter claims in torts arising in the torts declared on, ${ }^{31}$ but to one action for tort they do not allow the set off of a different tort ${ }^{32}$ nor the

${ }^{24}$ Code Civ. P. (N. Y.), Sec. 500. Cf. 2 Daniell Chancery Practice; edition of 1851, 814 Langdell Eq. Pl., Sec. 68.

${ }^{25}$ Dobson $v$. Pearce, $12 \mathrm{~N}$. Y., 156 . For an elaborate exposition of answers under the New York Code, see Bishop, Code Practice in Personial Relations. Sec. 187 , et seq.

${ }^{28}$ Code Practice, Sec. 194. The section of the Code is Sec. 501.

$2 \pi$ Nat. Fire Ins. Co. v. McKay, 21 N. Y., 191.

${ }^{28}$ Craigin v. Lovell, 88 N. Y., 258.

${ }^{29}$ Hopkins v. Lane, 87 N. Y., 501.

${ }^{80}$ This does not seem to have been expressly provided, but Mr. Bishop says that the courts have engrafted it.

${ }^{31}$ Bishop's Code Practice, Sec. 197. But see contra Smith v. Hall, 67

N. Y., 48; People v. Dennison, 84 N. Y., 272, construing the Code.

32 Rothschild $v$. IWhitman, 132 N. Y., 472. 
set off of a claim by way of contract.ss The defendant is not required, however, to plead by way of counter claim. He may avail himself of a separate action. ${ }^{34}$

Upon this brief statement of the theory of defenses under the New York Code, it is apparent that nothing is gained that has not been repeatedly accomplished in common law States by the allowance of equitable defenses in common law suits, and by the usual statutes of set off and recoupment. ${ }^{35}$

If then little has been accomplished by the uniform procedure under the codes in broadening the scope of the defense, ${ }^{36}$ the chief remaining inquiry is how far the new system is an improvement in determining the issues, and bringing the claims to adjudication.

It is evident that no satisfactory answer to this inquiry can be reached by comparison and the examination of decisions alone. It is too largely dependent upon experience in the intimate relations of practice. Therefore, resort must be had to opinions; and none could be more apt than that of Wm. B. Hornblower, Esq., one of the leading practitioners of the New York Bar, expressed in a speech to a bar association in New Jersey, an old system State: "Do not be led astray by specious arguments in favor of reformed procedure. Be content to let well enough alone. You have the State of New York before you as a terrible example. I believe our practice is infinitely more technical than that in New Jersey. Even the attempt to abolish the distinction between law and equity practice have been dismal failures."

${ }^{33}$ People v. Dentison, 84 N. Y., 272; Mairs v. Manhattan Real Estate Ass'u., 89 N. Y., 498.

${ }^{34}$ Brozen v. Gallaudet, 80 N. Y., 413.

: ${ }^{85}$ The Alabama statute of set off, Sec. 5888 of the Code (that is, revised statutes) of 1907 is as follows: "Mutual debts, liquidated or unliquidated, demands not sounding in damages merely, subsisting between the parties at the commencement of the suit, whether arising ex contructu or ex delicto, may be set off one against the other by the defendant or his personal representative, whether the legal title be in the defendant or not; and such set off, if found for the defendant, extinguishes either in whole or in part, as the case may be, the plaintiff's demand.' This section; substantially unchanged since 1852 , is construed as broadly as the New York Code.

${ }^{36}$ Apparently some good has been gained under uniform procedure in allowing cross-pleading between co-defendants in actions upon legal claims: Civ. Code, N. Y., Sec. 521. Of course this provision does not extend the court's jurisdiction in equity, however. Albany City Savings Inst'm. $v$. Burdick, 87 N. Y., 40.

${ }^{37}$ Quoted in Andrews' Am. Law, 2nd Ed., Sec. 635, where a resumé of other opinions may be found. 
Since the new procedure was first established in New York by the Code of 1848 , it has been amended and revised by almost annual enactments, until it has reached its present expanded condition, so uncompromisingly condemned by Mr. Hornblower; and so perhaps his opinion represents the extreme view of attempts at a uniform system. But when it is recailed that the object of 'the first New York commission was simplification, and that after sixty years of presumably desired amendments, the new system has in turn reached the point where the same outcry for simplification is again heard, it is evident that this chief value of the system has been lost, if indeed it was but possessed except in theory. ${ }^{38}$ Nor can it be doubted that the New York practice is equally as productive of "technical reversals" and delays as the systems in vogue in common law States, when we read the opinions of the judges quoted in the reports of the "Law's Delay Commission", published a short time ago. ${ }^{39}$

The working out of the reformed procedure in England under the Judicature Acts and the rules provided for by them, is more instructive from the evident fact that the Acts and Rules were more carefully prepared than the Code of Procedure in New York. That the English reform should have turned out in any important respects disappointing, therefore, should give to future reformers significant warning. The origin of the first Act of 1873 and the Rules appended to it, has already been given. But the Act was practically rewritten in $1875,^{40}$ and under the authority in the first act to the Queen in council to change the rules, the rules were entirely rewritten in 1883 . Therefore, when we refer to the English system of courts and procedure, we mean the system embodied in the Act of 1873 and twelve successive amendatory or enlarging Acts from I875 to I899, together with

38 "The Association of the Bar of the City of New York has recently acted upon the report of its special committee appointed some time ago by the President, Mr. Edmund Wetmore, to consider the subject of the simplification of New York Procedure." See an editorial on "Simplification of Procedure" in The Bench and Bar for January, 1910.

${ }^{30}$ For the general reader an available verification of this is the verbatim quotations which appear in Appendix D of the report to the American Bar Association, 1910, of the special committee "to suggest remedies and formulate proposed laws." Compare also certain amendments to appellate procedure proposed by the Association of the Bar of the City of New York, and the criticisms thereon appearing in The Bench and Bar for March, 1910.

${ }^{40} 38$ and 39 Victoria Ch., 77. 
the system of rules adopted in 1873 , recast in 1883 , and altered and revised to date. And for the convenience of practitioners and the courts, the entire system is republished yearly under the name of The Yearly Supreme Court Practice, showing how each section of the several Acts and rules had been amended or repealed. ${ }^{41}$ The acts, rules, and adopted forms, together with appropriate annotations, make a volume of more than eleven hundred pages of small print, exclusive of indexes and tables of cases. So that it will hardly be contended that simplicity is one of the virtues of the system. Nor does it appear that this multiplication of orders and methods of determining issues between litigants has resulted in materially speeding causes to final judgment or in curtailing costs. ${ }^{42}$ And while it was hoped that the opportunity to present all phases of a cause in one suit would tend to simplify the issues, ${ }^{43}$ some of the ablest English jurists now regard the new system as inefficient to that end, especially where common law rights are involved, since the rules do not require sufficient accuracy in the pleadings to distinguish the confessed from the denied.44

The success or failure of the different details of the English reform pleadings is impossible for us to determine from merely general criticisms. But since the disappointment in determining issues by the new method, is directly traceable to the inexactness of the pleadings, and since the first troubles seem to have been experienced in obtaining the simple statements required, ${ }^{45}$ it is evident that the difficulty lies in the pleadings.

The scope of the defense is much broader in England than in New York or in jurisdictions like Alabama or New Jersey, which retain common law pleadings. The defendant may set off or make counter claim of any demand which he could prosecute his own action to enforce ${ }^{40}$ the only limitation being that the judge

41 Edited and annotated by Muir Mackenzie, Willes Chitty, Lushington and Fox.

${ }^{42}$ In a speech in the House of Lords in 1880, Lord Esher deprecated the delay and expense of trials, which he regarded as having been increased by the Judicature Acts. Sec. 29 Ency. Britt., 10th Ed., 292.

4313 Ency. Britt., 9th Ed., 764.

44 See language and views of Lord Davey in 30 Ency. Britt., 10th Ed., 146, 1903; Sir Frederick Pollock: The Expansion of the Common Law, 1904, and his further opinion quoted in Andrews American Law, 2nd Ed., Sec. 635 , note.

45 See 13 Ency. Britt. 9th Ed., 763.

to See Order XIX, rule 3 , and cases sited in the Yearly Practice. 
or court, upon objection taken, may decide that the cross-claim cannot be conveniently litigated with the original claim and so order the parties to proceed with the original suit. And the same is true of claims made by the plaintiff in reply. ${ }^{47}$

Of course the value of this extension in the English practice depends entirely upon the perspicacity of the presiding judge; and few American States would be willing to confer such latitude of action on their lower courts. It may well be assumed, therefore, that no such extension of American State court practice will be made; although its merits may not unlikely appeal to those who revise Federal practice in the United States, where the District Judge is the accepted arbiter of so many other important points in a cause.

The same extension of scope of the action is the chief difference in principle between the plaintiff's pleadings in England and the plaintiff's pleadings in New York. He must make only a summary statement of the material facts upon which he relies without reciting the evidence. ${ }^{48}$ And "where the plaintiff seeks relief in respect of several distinct claims or causes of complaint founded upon separate and distinct grounds, they shall be stated, as far as may be, separately and distinctly." ${ }^{49}$ But this statement and the defendant's answer and the plaintiff's reply, although made out of court, in about the same way in England as in New York, after the issue and execution of summons and the docketing of the cause, are made in very inexact prescribed forms in England; and as the pleadings do not appear of record until the trial, effective amendments are evidently made very freely. So there does not seem to arise in England the trouble often experienced in New York of stating one cause and failing in the suit, because the evidence is found to develop a different cause. Moreover,-and this is the important feature,- the plaintiff is not limited in England as to the nature of causes he may join except by the power of the judge to determine that inconvenience renders the joint trial undesirable..$^{50}$

It is therefore apparent that the chief value of the English system (apart from details which cannot be discussed here) consists in the breadth of its scope of statement; and this would be pre-

47 These observations are taken from the Yearly Practice for 1905; pp. $266-268$.

48 Order XIX, r. 4.

49 Order XX, r. 7.

50 Order XVIII, r. 1. 
eminent but for its chief defect as appears from the opinions of the critics, which consists in the uncertainty of the issues, the only controlling factor being the discretion of the presiding judge. Under the New York system, on the other hand, if the difficulty of determining issues has not been so much complained of, it is due to the early judges having assimilated the system so nearly to that of the common law, that the statement acquired the rigidity of the common law declaration. ${ }^{51}$

We may therefore safely conclude from the experience of England on the one side and that of New York on the other, that the results of a simplified uniform system of procedure have not been entirely reassuring; and that if the plan is to be pursued by future reformers, the extremes to be avoided are too much flexibility on the one hand, and too much rigidity on the other. Every approach to uniform procedure has been made at the expense of eliminating many of the distinctions which identify the rights of the parties; and the necessity of stating these rights safely and yet with sufficient ellipsis to admit of apparent uniformity, is the chief problem with which reformers have to cope. The English attempted to accomplish this by providing a quantity of specified forms and abolishing demurrers. ${ }^{52}$

It must always be borne in mind that reforming procedure, as the term has been understood in England and America; contemplates no change of legal rights. Reformers endeavor to preserve these under the name of "substantive" rights, or "substantive law," and attempt to differentiate abstract rights from the concrete application of them, by calling the process of their application, remedies. Thus the special committee of the American Bar Association appointed to suggest remedies and formulate proposed laws, reported to the association in I910, as one of their principles of practice reform that "courts should have power and it should be their duty in every sort of cause or proceeding to

51 Criticisms of the early New York courts for bringing about this rigidity, as that by Henry A. Forster, Esq., found in 20 Bench and Bar 89 , for March, 1910, are hardly justified when it is recalled that the New York judge has not the power to decide that a cause must be separated into convenient parts as the English judge may do; for the parties determine their issues in New York. And therefore the confusion would have been hopeless without accuracy of statement in the complaint.

52 The forms were provided when the rules were recast in 1883, and demurrers were abolished at the same time. See The Yearly Practice volumes. 
grant any relief or allow any defense or cross demand which the facts show and the substantive law may require." 53 And they deprecate separate forms of actions, for the reason they say, that "wherever there is a separate form, men tend to assume that there is a distinct substance, whereas the sole question aside from due notice to one's adversary, may be one of remedy."

The framers of the New York Code of 1848 , and the draughters of the English Judicature Act of 1873 , did not hit upon the descriptive term "substantive law," but they both recognized the same distinction between rights and remedies, the New Yorkers when they provided that "The distinction between actions at law and suits in equity, and the forms of those actions and suits, have been abolished," vided that the courts "shall have power to grant **** all such remedies whatsoever as any of the parties *** may appear to be entitled to in respect of any and every legal or equitable claim properly brought forward by them." notion of "substantive law" by the words "action" and "claim" respectively, is not as successful as may have been desired, but the notion of an action or a claim, apart from a specific method of informing it is meaningless, unless taken as representative of the legal relation between the parties in the light of some accepted legal principle.

It is clear, then, that a right as defined for the purpose of enforcement under the old pleading at common law or under the old English procedure in Chancery, is not supposed to be lost or to be rendered less effective when defined for enforcement under the New York Code, or under the system of uniform procedure now in force in England, or when stated in conformity with any of the statutory changes in pleading provided throughout the various United States. But pleading a right under the old common law consisted solely in the selection of the form of writ desired, or believed to be obtainable by the plaintiff, and the statement of every fact the occurrence of which was necessary in order to inake up or to defeat, as the case might be, the plaintiff's right to the writ. That is to say, the pleader was required to describe definitely his right. And he was required to do no more: for. if

5335 Reports of Am. Bar Ass'n., p. 642 (1910).

s4 ibid, p. 644 ..

${ }^{55}$ Code of 1848, Sec. 69 (Now Sec. 3339).

os Act of 1873, Sec. 24 (7). 
he stated more than was necessary, he was guilty of prolixity, if not of duplicity. If, therefore, the right remains the same under new systems of pleading, it is evident that the reforms consist in allowing, or requiring the pleader to omit from his statement the averment of some of the facts which go to make up his right; that is to say, in eliminating from the pleading much of its former definiteness. The common law has been nowhere intentionally changed, and equity has been nowhere abolished. ${ }^{57}$ The aim of reformers is merely to establish and enforce the old rights in a shorter way.

To grasp the purpose or principle of procedure reform, then, it is necessary to understand what is involved in the application of the old legal rights by a new way, and incidentally, to determine what is meant by the term remedy. Complaint has frequently been made of the system of English or common law on account of the inaccuracy of its expressions. Indeed, much of the trouble lies even deeper, inhering in the English language. To the schoolmen who follow the approximate accuracy of Latin it is baffling to express the immensely different ideas involved in the words "jus" and "lex" by the same English word "law"; or to follow the Germans in their methodical analysis of "rechts", and the Frenchmen with their discussions of the corresponding "droits", without far overstepping the limitations implied in our English term "rights". ${ }^{\circ}$ If, therefore, our trained scholars and essayists

${ }^{57}$ Report of Special Committee to suggest remedies. 35 Rep. Am. Bar Ass'12., 644. And see English Judicature Act of 1873, Sec. 24, sub-sections 4 and 6 , as follows: (4) "The said courts respectively (i. e., the new courts created by the Act) and every judge thereof, shall recognize and take notice of all equitable estates, titles and rights, and all equitable duties and liabilities appearing incidentally in the course of any cause or matter, - fn the same manner in which the court of chancery would have recognized and taken notice of the same in any suit or proceeding, duly instituted therein before the passing of this Act." (6) "Subject. to the aforesaid provisions for giving effect to equitable rights and other matters of equity in manner aforesaid, and to the other express provisions of this Act, the said courts respectively, and every Judge thereof, shall recognize and give effect to all legal claims and demands and all estates, titles, rights, duties, obligations, and liabilities existing by the common law or by any custom, or created by any statute, in the same manner as the same would have been recognized and given effect to if this Act had not passed, by any of the courts whose jurisdiction is hereby transferred to the High Court."

"s Pollocks First Book of Jurisprudence, 17. Compare. however, Austin, Vol. 1, 257, note. 
are often at a loss to express themselves clearly with the words they have to use, it is not surprising that our practical reformers sometimes fall short of their aim when endeavoring to use new language to express old rights, and to do so concisely and without changing the thoughts. It is not too much to say that the difficulty of the task has not always been appreciated by the reformers themselves, but if the plan of their work, as revealed in reform systems now in operation contemplates no change in existing rights, we may be sure that they intended to destroy no existing remedies.

What, then, is a remedy? We do not find Littleton or Coke or Blackstone, of the early days, making any such distinction as that between rights and remedies; nor Stephen, nor Story, nor Daniell among the modern masters. At the birth of the common law, lawyers may be said to have considered remedies, for, at that time, they knew nothing of rights. Glanville, the Chief Justice of Henry II., the author of the first common law book, prepared for us little more than a list of writs.5 But by the end of the first half of the nineteenth century, the Golden Age of the common law, when relations and obligations between men had become definable, lawyers and judges were talking of rights and the enforcement of them; and then in so far as rights were recognized, remedies were no longer needed. That is to say, a right involves a definite obligation, and a duty, based upon a conceivable principle of jurisprudence; whereas a remedy involves a search for indefinite relief based upon an indefinite sense of injury: When the remedy is found, it is identified as a right, and its converse is an obligation or a duty. ${ }^{\circ 0}$ "Remedy", then, is a lay term; and the use of it in the modern statutes and by the modern encyclopæedists to indicate classifications of rights more or less alike and applicable to nearly similar aggregations of facts, has obtained for it undue emphasis by the lawyers. ${ }^{81}$ If we mean

${ }^{50}$ Glanville de legibus Angliae.

${ }^{60} \mathrm{It}$ seems desirable to avoid as much as possible the language ordinarily found only in works upon jurisprudence; because they assume some previous reading and lead directly into the Roman Law. Therefore rights have not been referred to as being themselves obligations. But if the correctness of the position taken in the text is doubted, the reader has merely to find a meaning of remedies in the language of the schoolmen.

B1 Sir Frederick Pollock is quoted as saying in a lecture to the law students of Columbia University on Oct. 3, 1911, the following: "Technical 
by a remedy the generic term which embraces all the writs issuable out of courts, commanding a defendant to give a plaintiff specific relief, as a mandamus to do an act, or an injunction to refrain from doing an act, or an order to make a deed, we may use the word remedy accurately. But if we mean by a remedy a form of action to which a certain state of facts entitles a plaintiff, then we necessarily imply the plaintiff's right to the remedy, growing out of the particular group of stated facts; and the distinction between the right and the remedy is gone. If then reformers create new remedies, they create new rights, and add to the existing rights, which they profess not to abridge. "i2

By the common law a plaintiff who had been deprived of a chattel had no way to recover it, although openly exhibited by the defendant, unless it was of such peculiar value as an heirloom, when equity would entertain his complaint. ${ }^{63} \mathrm{He}$ could recover its value as damages,-if it had been forcibly taken away, by the action or writ of trespass de bonis asportatis; if it had been originally lawfully taken away, then by the. action or writ of detimue; or if casually found and converted, then by the action of case in trover - but never had the plaintiff a right to anything but damages. Reformers have generally seen the wisdom in modern society for the plaintiff to be allowed to recover his specific chattel, and so they have generally added to his former rights the right to recover chattels specifically. ${ }^{\text {s4 }}$ But in providing this new remedy, they have evidently provided also a new right. Every remedy therefore, imports a distinct right; and if the converse is questioned that every right imports a distinct remedy, let it be

dialectic is an excellent servant; the lay people may talk as they please 'after their own talent,' as the year books say, but every lawyer that has sat on committees knows that untrained amateur pedantry can be both more absurd and more unjust than any professional bias." Nezv York Times, Oct. 4, 1911.

62 See foot note (57) supra.

${ }^{63}$ III Blackstone Commentaries, 145 ; Somerset v. Cookson, 3 P. Wms., 390; 1 Gray Cases on Property, 18.

${ }^{64}$ Cf. Code of Alabama, 1907, Sec. 3782, allowing specific property to be recovered by the action of detinue. And see Code of South Carolina, 1902, Sec. 227 et seq. It is interesting to note that the English Judicature Acts and the Supreme Court Rules thereon, seem not to have added to the old common law rights. See Rules of Sup. Ct., 1883." Appendix A, Pt. III, Sec. IV, and Appendix C, Sec. VI, giving the forms provided for actions to recover personal property, always specifying damages in lieu thereof. 
recalled that no right without a remedy has ever been the shibboleth of the common law; and if such a right has ever been discovered it was valueless. ${ }^{65}$

Concluding then that rights and remedies are not to be differentiated, and that the purpose of reformers of procedure is not to alter rights but only to provide a simple way for their application and enforcement, it would seem that the problem of reforming procedure may be reduced to determining the extent to which the simplification of the statement of rights may be carried without impairing the effectiveness of pleading and the certainty of justice. The special committee of the American Bar Association appointed "to suggest remedies and formulate proposed laws" in its able report of I9Io, already frequently cited in this article, ${ }^{66}$ enumerated the purposes of pleading as follows: first, "to serve as a formal basis for the judgment"; secondly, "to separate issues of fact from questions of law"; third, "to give litigants the advantage of a plea of res adjudicata if molested again for the same cause", and fourth, "to notify parties of the claims, defenses and cross-demands of their adversaries". ${ }^{67}$ And without agreeing with the report that compliance with the fourth purpose by reformers will substantially fulfill the ends in view, all will probably admit that a system of pleading may be ever so simple if it complies with each of the four requisites which the committee has named. When, therefore, reformers propose that the pleadings in all actions shall be in the same simple form, it is assumed that the above four principles of pleading are to be complied with and that the simple form, when fitted to a concrete case, will not be too indefinite to reveal the particular rights for which the parties contend.

It will now be apparent that the theory of a uniform procedure, in its original sense of a single form of action, with one simple statement of the facts involved, is in conflict with fundamental principles of jurisprudence. Law is the science of rights, and litigation involves nothing more than their logical presentation and adjudication. Procedure "is the mode of proceeding by

${ }^{65}$ The writer elaborated this idea somewhat in an article to be found in report of the proceedings of Alabama State Bar Ass'n., 1908, in which he called attention to the fact that the line between equity jurisdiction and equity procedure was purely imaginary.

6035 Reports An. Bar Ass'n., 614.

67 ibid, p. 638. 
which a legal right is enforced ;", and presupposes the claim of a right. To state mere facts and circumstances without claiming and averring the infringement of any specific right or rights, does not present a cause of action,-is not a juridical proceeding, even if it were practicable. But there is no doubt of the advantage to society to be derived from a system which would allow plaintiffs and defendants to bring all their claims before the court at once, without danger of error or omission, and have the court select and enforce the rights to which they are entitled. And since even this is impracticable where the supposed rights are many, the nearest approach to the desired end is to allow the rights to be stated so briefly and in so nearly the same language, that one may readily be amended into another before final judgment; and to allow all sorts of rights to be claimed in the same suit.

This seems to be the gist of the English attempt at a uniform system of pleading $;^{69}$ although New York and other American systems limit the claims which may be pursued together to certain classes. $^{70}$ To avoid delay by amendment and a needless election of remedies the additional privilege of setting out several distinct statements of rights in the same action is allowed, as we have seen, but that does not differ in its theory from common law counts, and is an abandonment of uniform procedure as a theory. Moreover unless the joinder of actions is limited to certain classes, or by the discretion of the judge, as in England, the issues must become hopelessly entangled.

But however sound the theory may be that a complaint ought to charge the infringement of some specific right in order to institute an action, and put the defendant upon the defensive, some will doubtless deny the correctness of the position that it is impracticable to require plaintiffs to present to the court only facts and circumstances, praying simply for an adjudication of the rights involved. And they will base their denial upon the old chancery prayer for general relief.

Undoubtedly it was the custom ounder the early English practice before the chancellors for the plaintiff to file his bill present-

6831 Cyclopaedia of Law and Procedure, 1153, citing Opp. $v$. Teu Eyck., 99 Ind., 345, 351 ; Payser $v$. Minors, 7 Q. B. D., 329, 333. "An action is nothing else but the demand of right." Mirrour of Justice, Ch. II, Sec. 1.

'Rules of Supreme Court Order XVIII.

${ }^{70}$ N. F. Code Civ. Proc., Sec. 484; South Carolina Codé Civ. Proiedure, Sec. 188. 
ing merely a statement of facts followed by a prayer for such "relief as the facts might warrant without suggesting the nature of relief desired. ${ }^{71}$ And while it was later the custom in England and America to precede this general prayer with a prayer for the specific relief to which the plaintiff thought himself entitled, ${ }^{72}$ yet this special prayer was in no sense the accurate statement of a right. It is therefore necessary to explain why this old practice may not be applied to law as well as to equity, and be made the basis of a uniform system.

The nature of a suit at law and that of a suit in equity an essentially different. And that is another fundamental principle which has been overlooked by many advocates of a uniform procedure. To accomplish by the enactment of a statute "the abolition of the distinction between actions at law and suits in equity," ${ }^{73}$ and at the same time to retain our English system of law is as impossible as to abolish by statute the points of the compass.

"Anciently it was essential to the due institution of all actions in the" common law courts, "that they should commence by original writ." And the original writ was "a mandatory letter issuing out of the Court of Chancery, under the great seal, and in the King's name, directed to the sheriff of the county where the injury is alleged to have been committed; containing a summary statement of the cause of complaint, and requiring him to command the defendant to satisfy the claim; and on his failure to comply, then to summon him to appear in one of the superior ccurts of common law, there to account for his non-compliance." "These instruments have consequently had the effect of limiting and defining the right of action itself; and no cases are. even now considered as within the scope of judicial remedy, in the English law, but those to which some known original writ (when these instruments were in universal use) would have applied, or for which some new original writ, framed on the analogy of those already existing, might, under the provisions of the Statute of Westminster 2 (I3 Edward I.) have been lawfully devised. The

711 Daniell Chancery Pr., Perkins Edition, 434.

72 ibid. And see Story Eq. Pl., Sec. 42.

${ }_{73} N$. Y Code Civ. Proc., 3339. It will be noted that the English Judicature Acts contain no such provision. 
enumeration of writs, and that of actions, have become in this manner identical." "T4

Therefore a suit at common law must needs be an action setting forth a claim recognized as analogous to one which has already been enforced by some one of the original writs. In such case the plaintiff is recognized as having a right to the writ. And on account of certain defining averments in the several writs, as "covenant", or "debt", or "trespass", or "dower", and so on, the actions have come to be distinguished by those names.

It does not seem to be established at what time the invention of new original writs ceased to be pursued; but after the ordinary instances of oppression by one of the King's subjects upon another had been made cognizable in the law courts, ${ }^{75}$ the drafting of a new writ seems to have been difficult to obtain. Certain it is that as early as the reign of King Richard II, the commons were willing that the Chancellor or the King's Council might call a party to answer if a remedy were not given by the common law. ${ }^{76}$ And in time it became recognized that cases frequently occurred in which the machinery in vogue in the common law courts, as well as the limitations of the original writs, rendered the award of justice by the common law impracticable. To such cases were applied the "extraordinary jurisdiction of the court of chancery;" and that constitutes the chief domain of what is called "equity" in our day.

"The application to this extraordinary jurisdiction, instead of being in the form of a writ, prescribed by settled law, seems always to have been in the form of a petition of the party or

${ }^{74}$ Stephen, Pleading, pp. 5, 6, 8. This excellent statement of elementary legal history from Stephen's classic work is copied almost verbatim, although it was on the tongue of every law student of a few years ago, because its bearing upon the establishment of a uniform procedure seems to have been universally overlooked. Compare also, 3 Blackstone Com., 273.

75 It was the opinion of Fairfax, a judge of Edward IV, that if the writs had been a little further extended, the development of the extraordinary jurisdiction of the Court of Chancery would have been much abridged. Y. B. $21 \mathrm{Ed}$. IV, 23, quoted in $3 \mathrm{Bl}$. Com., Cooley's Edition, 51, note.

${ }^{76}$ In 13 Richard $I I$, the commons prayed that no party might be required to answer before the Chancellor for any matter where a remedy was given by the common law. See Story Eq. Jur., Sec. 46. And for a thorough discussion of the rise of equity jurisdiction with the various authorities compared, see Chapter 2 of that wonderful work of Justice Story. 
parties aggrieved, stating the grievance, the defect of remedy by proceedings in the courts of common law, and the remedy, which, it was conceived, ought to be administered. This mode of proceeding unavoidably left every complaining party to state his case according to the particular circumstances, always asserting that the party was without adequate remedy at the common law."

Rights in equity, then, may be said to embrace the unclassified residuum not specifically recognized by the common law; ${ }^{78}$ and the essential nature of a suit in equity is its appeal to the chancellor to award someone of these indefinite rights.

In such cases it may well be that the petition of the subject to the King or his chancellor partook largely of a prayer for advice, as well as a prayer for mercy. At all events it invoked primarily the protective intervention of the sovereign through his officer, ${ }^{79}$ and in that light it is evident why the statement of a story rather than the claim of a right was the proper procedure.

It is therefore apparent, that the proper use for such petitions has always been the exceptional cases, limited by the time honored final decree that the plaintiff has a remedy at law. And so it cannot be seriously maintained from the example of a restricted jurisdiction, that the courts could administer justice successfully by a procedure which involves advising the parties of their rights as well as accurately adjudicating them.

Birmingham, Ala.

Henry Upson Sims.

77 Report of the Commissioners under the Chancery Commission, 50 Geo. 111, 1826, quoted in Story Eq. Jur., Sec. 49, note.

78 All old students of the late Professor James Bradley Thayer, of Harvard, will recognize the fitness of this term, "unclassified residum." He used to apply it to the "police power."

${ }^{79}$ F. W. Maitland, Equity: Also the Forms of Action at Common Laze. pp. $4-6$ 